\title{
Impact of gold prices on stock exchange market: a case of Karachi stock exchange market of Pakistan
}

\author{
Muhammad Shaique ${ }^{1 *}$, Abdul Aziz ${ }^{2}$, Gobind M. Herani ${ }^{3}$ \\ ${ }^{1}$ PhD Scholar, Zhongnan University of Economics and Law (ZUEL) P.R China \\ ${ }^{2}$ Lecturer, Department of Business Administration, Federal Urdu University of Arts, Science \& Technology (FUUAST), Karachi \\ ${ }^{3}$ Director, ORIC, Chairman, Department of Business Administration, Benazir Bhutto Shaheed University, Lyari, Karachi \\ *Corresponding author E-mail: shaiq33@live.com
}

\begin{abstract}
The objective of the study is to examine the long-term relationship between gold prices and KSE-100 index of the Karachi stock market Pakistan. For the foreign and domestic capital investors, it is assumed that the gold is the safest heaven for making investment. On the other handstock markets are considered highly volatile. This study uses monthly data of two hundred forty eight months from October 1993 to May 2014. Time-series data of both variables Karachi Stock Exchange 100 index (KSE-100) and gold prices have been collected from the official website of Karachi stock market and Forex.com. To achieve the aims of the study, several econometric tests have been applied such as unit root test by using Augmented Dickey-Fuller test, Johnson Co-integration test and Vector Auto-regressive Model (VAR). This study finds that there is no long-run relationship between KSE 100 index and gold prices. It is concluded investors should not consider KSE 100 index and gold prices as close alternatives rather they should make their decisions on subjective knowledge by aligning them with empirical evidence. While making decisions about gold prices last month's price must be taken into consideration because current gold price is significantly influenced by last month's gold price. Whilst making decision regarding KSE 100 index last two months' fluctuations taken into consideration.
\end{abstract}

Keywords: KSE-100 Index; Gold Prices; Economic Development; Capital Investment.

\section{Introduction}

Gold is the most leading indicators of the economic development. It replicates with core fundamental of the economic variables. Gold is considering as very precious and unique metal on the earth, since ancient era. The main objective of this paper is to examine, evaluate, establish, conclude and assess the impact of gold prices on KSE-100 index and to identify the relationship between gold price and stock market index. Rising of business trends in KSE-100 index is attracting potential capital investment. The main objective is to diversify the people from precious metal, especially gold. The trend may not last long and sudden change in economic factors. In such as scenario, it is very necessary to study, scrutinize and establish a relationship between them.

Globally the economic conditions are encouraging gold prices to move further upward. The recent regional invasion of Saudi Arabia in Yemen may become cause to put the gold price in high motion. Increase in the prices of the gold has been noticed from last few decades. If the situations change, more investment can be expected in this index.

According to (Bhunia, and Mukhuti, 2013) gold price rises when there is a bearish outlook of the economy or some uncertainty over the future. Gold is ancient, precious, highly liquid, financial instrument, and it categorizes in very important asset class. It has both features of commodity and currency, but storage cost or safe keeping of gold makes it different from the paper and electronic currency. Many researches have been carried out in order to find this very important causal relationship between gold and stock indices. The empirical evidence suggests that gold prices can significantly impact on the stock prices (Tufail, and Batool, 2013). The global economic chaos is probably motivating abstruseness in gold prices. It is riskier for the investors to invest in the stock exchange of developing countries. Several researchers attempt to explore the long and short term relationship between gold prices and stock market in different dimension. The global economic crisis of 2007 created a credit crunch in the financial institutions of the world where investors lost billions of dollars (Nor, 2012). Huge capital lost to make investors more terror for new investment. Investors should have to invest their capital in gold because in any circumstances of crises the market value of gold remains consists and stable.

Some researchers proposed that stock exchange or stock indexes are the best reflection of healthy economy, due to the large size and being the market place. A detail of historical data suggests that, in case of decrease in the dollar value or any uncertainty in the stock indices around the world, the price of Gold increases (Shahzadi and Chohan, 2013).

China, Australia, USA and South Africa are the largest countries in terms of producing gold and USA; India and China are the top countries that are consuming most of the gold all around the world. Pakistan is facing problems, economically, socially and politically, with every day passes by an uncertainty, and it has been observed that in time of crisis, investors are investing in gold the same phenomena can be observed here in Pakistan. The Karachi Stock Exchange and KSE-100 index another most recognized indices around the world followed the same pattern, i.e. in times of downturns people are heavily investing in gold. The crux of this 
study is to examine the relationship between gold and stock indices.

\section{Literature review and hypothesis develop- ment}

Most economists and investor consider the gold as it is the leader commodity in the stock market; it is a safe haven as industrial commodity and investment assets (Shahzadi and Chohan, 2011). Gold commonly knows as it is the risk less for investors, the unique characteristics of gold depends on the less susceptibility to exchange rate fluctuations. It seems that gold has the ability to the resist change in the external and the internal purchasing power of the local currency (Le, and Chang, 2011).

The domestic gold prices in India are rising on a very heavy demand, the major reasons are it is liquidity assets, security and expanded portfolio commodity. In the historical period, whenever the stock market is being collapses or when the dollar rate fallen down gold prices considers as the safe heaven on the earth, and its prices also remain same or move upwards for a period (Bhunia, and Mukhuti, 2013).

Under the system of flexible market exchange rates disequilibrium in the payment process is constantly adjusted, there is no convincing reason to ensemble, gold growths and capital flows in proper way and made it with the regulatory authority system of the country (Ahmad, et.al 2014). The global economy is facing the international crises and it also faces several uninvited climates that hitting the economic condition of the world with direct and indirect factors of economics, due to that every country facilitating the foreign and domestic investors as they invest their capital in the stock market so that economic crises arrow move downward (Hassan, 1998).

Although gold has no longer over commands the monitory policy standards of the country, it constantly obtained attractive situation for the investors, manufactures and consumers across the world. In India total revenue of the gold producers and retailer $\$ 20$ billion in a year (KANNAN, and DHAL, 2008). In addition, six billion turnover of IMF of gold is initiated for concessional funding to the developing or poor countries over the next two to three years (United Nation, 2009). The monetary policy system was created to make secure the appropriate turnover of money over the country by setting up the standards, procedures and policies that monitor the supply and demand of money. It's designed by the main body of government of a country and applied to the whole country accordingly (Nor, 2012). Economic climates are analyzed through the major variables such are the increase in interest rate, real exchange rate, investment, and central part of the macroeconomics of the economic development (Jordaan, 2013).

The potential gold market has a significant impact on the inflation, while the main government body and stakeholders in the stock market are designed and adopting the new policies and procedures' practices for the sustainable development of the economy. Such as, the gold prices are the fix and not changeable for a long period that's why investors wish to invest into the gold. Gold prices are serving as the leading indicators for the inflation (Ziaei, 2012). Gold prices control the inflation instability, and it also offers several unique situations with dynamic opportunities (Saira and Batool, 2013). Furthermore, from the few recent years of the development of the economy, in the era of 2008, the sharp rising of gold prices makes crises condition in economic stability that faces the uncertainty in the global economy Saira and Batool, 2013).

Mahdavi and Zhou (1997) concluded that there is no long-run significant relationship between gold and stock indices. A study conducted in India by (Ratanapakorn, and Sharma, 2007) concluded that the gold price is highly interlinked with international market and domestic market in India. Additionally, Foreign and international investors invest their capital into safest commodity of the economy, as the gold is the real place for stock market development, and it also being caused the real development of financial institutions that force the sustainable development in the stock market (Nadeem, Zakaria, and Kayani, 2014). Gold is becoming the indorse insurance of the uncertain economic condition of delicate macroeconomics, economic variables; perform more strongly and significantly with these factors. Maximum capital investment in gold market plays the dynamic role as the protection from the very poor inflation (Shaheen, 2013).

\subsection{Hypothesis I}

H1: There is a long term relationship between gold prices and KSE-100 index;

There are many industrial commodities that have dynamic impact on stock prices and one of them is gold (Soni, and Ajay, 2015). According to study published by Moore (1990) he finds out that there is a negative relationship between gold and stock indices and whenever the price of stock moves upward the gold prices move downwards. He studied the data for 12 years from 1970 to 1988 . Other researchers concluded the same result; a similar study was conducted in turkey by (Büyükalvarc1, 2010). In which researcher has taken many variables to study the impact of those on stock indices and found that gold is the most prominent and significant variable and considers as the alternative investments for investors. Gold is still considering as a store of value "without escalation" whereas stocks are regarded as a return on value escalation from the probable real price increase plus dividends (Wogan, 2010). The recent crisis of economic climates has changed the opinion of investors, and once again investors are converging in gold investments. This change was witnessed after the global crisis of 2007 before that gold prices were very constant and no such increases value was observed, this conclusion also gave a foundation to the theory that in turmoil time period or in a recession, people tend to invest maximum capital in gold and consider it as a safe haven (Irshad. Et.al 2012)

Graham (2001) examines the long-term and short term relationship and concluded that short term causality exists but long-term equilibrium between the gold price and stock market indices. Further concluded that in short term stock prices are affected by gold prices, but no such relationship is found in the long term. In addition, the short-term fluctuations create due to political instability, exchange rates, real interest rate and financial distress. They also concluded that there is a long and short term relationship of gold with stock indicators and found it to be very significant act (Sharma, and Mahendru 2010). So we hypothesize based on above literature.

\subsection{Hypothesis II}

$\mathrm{H} 2$ : There is a short term relationship between gold prices and KSE-100 index;

\section{Methodology}

\subsection{Research design}

This study attempts to test causal relationship between gold prices and KSE-100 index. It has also been attempted to find long term association between these two variables. To test the long-run association Johnson Co-integration test has been applied because it is appropriate tool to test equilibrium between two variables. Johnson Co-integration test requires that variables under consideration must be non-stationary at level and stationary after first difference. Therefore, stationary of data has been tested by using Augmented Dicky-Fuller (ADF) test. In case two variables are co-integrated with each other, Vector Error Correction Model (VECM) is applied to test long run and short causality. VECM finds the rate through which equilibrium will get restored, and short run causality is sought through Wald test. In case co-integration is not found, it is further verified by using Vector Autoregressive Model (VAR). Both in VECM and VAR, number of vectors (equations) 
are generated according to number of variables. Each variable is response variable in first vector and explanatory in preceding vectors. Both models capture the effect of last two periods on current period by taking $\operatorname{lag}_{\mathrm{t}-2}$.

\subsection{Sampling design}

This study uses monthly data of two hundred forty eight months from October 1993 to May 2014. Time-series data of both variables Karachi Stock Exchange 100 index (KSE-100) and gold prices data have been collected from the official website of Karachi stock market and Forex.com. It has been attempted to meet all the assumptions of time-series data. For the purpose of analysis eviews software has been used.

\section{Data analysis}

\begin{tabular}{|c|c|c|c|}
\hline & Critical Values & t-statistics & Probability \\
\hline \multirow{3}{*}{ KSE-100 Index } & $1 \%$ level & -3.808546 & \multirow{3}{*}{0.2558} \\
\hline & $5 \%$ level & -3.020686 & \\
\hline & $10 \%$ level & -2.650413 & \\
\hline \multirow{3}{*}{ Gold Price } & $1 \%$ level & -3.788030 & \multirow{3}{*}{0.8553} \\
\hline & $5 \%$ level & -3.012363 & \\
\hline & $10 \%$ level & -2.646119 & \\
\hline
\end{tabular}

Table 1 summarizes the results of ADF test at level to check the stationary of data. Probability values are greater than 0.05 , we fail to reject the null hypothesis data has unit root. Therefore it is concluded data is non stationary at level.

Table 2: Stationary Test after First Difference

\begin{tabular}{llll}
\multicolumn{4}{c}{ Table 2: Stationary Test after First Difference } \\
\hline & Critical Values & t-statistics & Probability \\
\hline \multirow{3}{*}{ KSE-100 Index } & 1\% level & -3.831511 & \\
& 5\% level & -3.029970 & 0.0605 \\
10\% level & -2.655194 & \\
Gold Price & 1\% level & -3.808546 & \\
& 5\% level & -3.020686 & 0.0042 \\
& 10\% level & -2.650413 & \\
\hline
\end{tabular}

Table 2 summarizes the results of ADF test after first difference to check the stationary of data. Probability values are $6.05 \%$ and $0.42 \%$ respectively. It is found that both variables are stationary after first difference. It is desirable because this data meets the requirements of co-integration test. In the following sections cointegration results have been presented.

GOLD

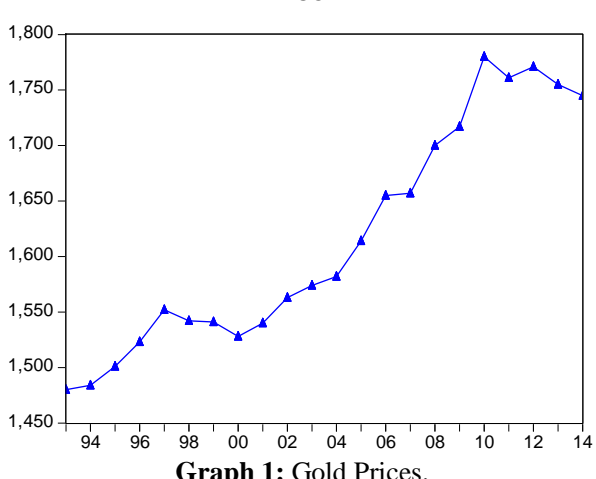

Graph 1: Gold Prices.
KSE100

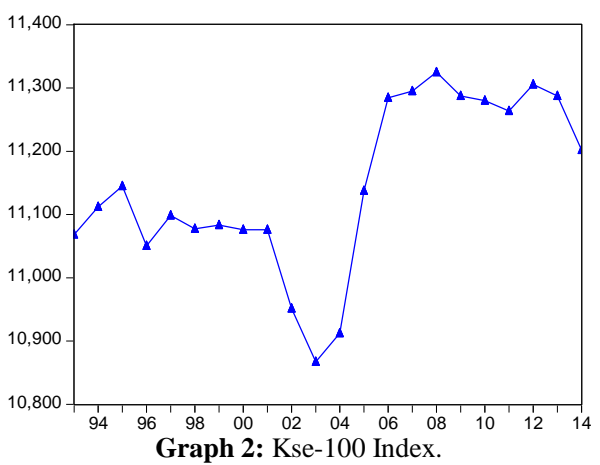

Graph 1 and 2 are given to show the graphical pattern of nonstationary data. Both graphs of gold prices and KSE 100 index are generated by using level data. These graphs show the pattern in the data so they confirm the non-stationary results generated by using ADF test given in the table 1.

Table 3: Johnson Co-Integration-Trace Statistic

\begin{tabular}{lllll}
\hline $\begin{array}{l}\text { Hypothesized No. } \\
\text { of CE }(\mathrm{s})\end{array}$ & $\begin{array}{l}\text { Eigen- } \\
\text { value }\end{array}$ & $\begin{array}{l}\text { Trace } \\
\text { Statistic }\end{array}$ & $\begin{array}{l}\text { Critical } \\
\text { Value }\end{array}$ & Probability \\
\hline None & 0.443434 & 12.30158 & 15.49471 & 0.1430 \\
At Most 1 & 0.028690 & 0.582197 & 3.841466 & 0.445 \\
\hline
\end{tabular}

Table 4: Johnson Co-Integration-Max-Eigen Statistic

\begin{tabular}{lllll}
\hline $\begin{array}{l}\text { Hypothesized } \\
\text { No. of CE (s) }\end{array}$ & $\begin{array}{l}\text { Eigen- } \\
\text { value }\end{array}$ & $\begin{array}{l}\text { Max-Eigen } \\
\text { Statistic }\end{array}$ & $\begin{array}{l}\text { Critical } \\
\text { Value }\end{array}$ & Probability \\
\hline None & 0.443434 & 11.71938 & 14.26460 & 0.1216 \\
At Most 1 & 0.028690 & 0.582197 & 3.841466 & 0.4455 \\
\hline
\end{tabular}

Table 3 and 4 present the results of Johnson Co-integration, probability values of none are greater than $5 \%$ in both tables. It confirms that there is no co-integration between KSE-100 index and gold prices. In case co-integration is not found, VAR model is applied. In the following sections VAR models are generated and results have been compiled by using VAR models.

Table 5: Vector Autoregressive Model with Dependent Variable KSE-100

\begin{tabular}{lllll}
\hline & Coefficient & Std. Error & t-Statistic & Probability \\
\hline $\mathrm{C}(1)$ & -0.052372 & 0.760408 & -0.068874 & 0.9460 \\
$\mathrm{C}(2)$ & 0.522107 & 0.752200 & 0.694107 & 0.4982 \\
$\mathrm{C}(3)$ & 1.150844 & 0.221876 & 5.186870 & 0.0001 \\
$\mathrm{C}(4)$ & -0.657014 & 0.219721 & -2.990221 & 0.0092 \\
$\mathrm{C}(5)$ & 4886.567 & 1655.993 & 2.950838 & 0.0099 \\
\hline
\end{tabular}

Table 5 summarizes the results of the following equation.

$\mathrm{KSE} 100=\mathrm{C}_{6} \mathrm{GOLD}_{-1}+\mathrm{C}_{7} \mathrm{GOLD}_{-2}+\mathrm{C}_{8} \mathrm{KSE}_{100}+$

$\mathrm{C}_{9} \mathrm{KSE} 100_{-2}+\mathrm{C}_{10}$

C (1) and C (2) coefficients represent lag 1 and 2 of gold prices. C (3) and C (4) coefficients represent the lag 1 and 2 of KSE 100 index. Finally $\mathrm{C}(5)$ is the intercept of the equation.

Third and fourth coefficients are KSE 100 index lag 1 and 2 respectively. Both coefficients are statistically significant. The results suggest that previous month's market fluctuations and the fluctuations of two months ago of KSE 100 index affect today's index. Other coefficients show insignificant results.

Table 6: Model Summary of Vector Autoregressive Model with Dependent Variable KSE 100

\begin{tabular}{llll}
\hline R-squared & 0.824493 & Mean dependent VAR & 11150.25 \\
\cline { 1 - 2 } Adjusted R-squared & 0.777691 & S.D. dependent VAR & 140.2314 \\
S.E. of regression & 66.11859 & Akaike info criterion & 11.43309 \\
Sum squared resid & 65575.02 & Schwarz criterion & 11.68203 \\
Log likelihood & -109.3309 & Hannan-Quinn criter. & 11.48169 \\
F-statistic & 17.61669 & Durbin-Watson stat & 1.950672 \\
Prob (F-statistic) & 0.000015 & & \\
\hline
\end{tabular}

Table 6 summarizes the results of model summary; all indicators suggest model is useful for the prediction. $\mathrm{R}^{2}$ is $88 \%$, it indicates 
KSE 100 index is explained by $88 \%$ with explanatory variables. Fstatistic confirms the validity of the model, Durbin Watson stat suggest there is no serial correlation. AIC, SC, and HQC are also closer with each other which are desirable for the estimated model.

Table 7: Vector Autoregressive Model with Dependent Variable Gold Price

\begin{tabular}{lllll}
\hline & Coefficient & Std. Error & t-Statistic & Probability \\
\hline $\mathrm{C}(6)$ & 0.932035 & 0.275537 & 3.382606 & 0.0041 \\
$\mathrm{C}(7)$ & 0.012961 & 0.272563 & 0.047551 & 0.9627 \\
$\mathrm{C}(8)$ & 0.033273 & 0.080398 & 0.413850 & 0.6848 \\
$\mathrm{C}(9)$ & -0.016298 & 0.079617 & -0.204709 & 0.8406 \\
$\mathrm{C}(10)$ & -87.20003 & 600.0575 & -0.145319 & 0.8864 \\
\hline
\end{tabular}

Table 7 summarizes the results of the following equation.

$$
\begin{aligned}
& \text { GOLD }=\mathrm{C}_{1} \mathrm{GOLD}_{-1}+\mathrm{C}_{2} \mathrm{GOLD}_{-2}+\mathrm{C}_{3} \mathrm{KSE} 100_{-1}+ \\
& \mathrm{C}_{4} \mathrm{KSE} 100_{-2}+\mathrm{C}_{5}
\end{aligned}
$$

C (6) and C (7) coefficients represent lag 1 and 2 of gold prices. C (8) and C (9) coefficient represent the lag 1 and 2 of KSE 100 index. Finally $\mathrm{C}(10)$ is the intercept of the equation. First coefficient C (1) is statistically significant; it means current gold price is affected by last month's gold price. Other coefficients show insignificant results.

Table 8: Model Summary of Vector Autoregressive Model with Dependent Variable Gold Price

\begin{tabular}{llll}
\hline R-squared & 0.952363 & Mean dependent VAR & 1630.050 \\
\hline Adjusted R-squared & 0.939660 & S.D. dependent VAR & 97.53352 \\
S.E. of regression & 23.95840 & Akaike info criterion & 9.402833 \\
Sum squared resid & 8610.077 & Schwarz criterion & 9.651766 \\
Log likelihood & -89.02833 & Hannan-Quinn criter. & 9.451428 \\
F-statistic & 74.97010 & Durbin-Watson stat & 1.987605 \\
Prob(F-statistic) & 0.000000 & & \\
\hline
\end{tabular}

Table 8 summarizes the results of model summary; all indicators suggest model is useful for the prediction. $\mathrm{R}^{2}$ is $95 \%$. It indicates gold price is explained by $95 \%$ with explanatory variables. Fstatistic confirms the validity of the model; Durbin Watson stats suggest there is no serial correlation. AIC, SC, and HQC are also closer with each other, which are desirable for the estimated model.

\section{Conclusion}

Karachi Stock Exchange plays a dynamic role in the mobilization of capital in Pakistan and plays a key role for the financial sector of the economy. While the Pakistani capital market is most volatile in nature and found among the most volatile economies of the Asia, where we have even viewed the upward and downward curve of 1000 points in a single day, and such volatility in stock market forces the investors to invest their capital in safe heaven like gold, invest in gold once initiates the safest investment to make a probable revenue, and this has stimulated the need to examine the relationship between the KSE-100 index and gold market. This research study has used Augmented Dicky-Fuller test, Johnson Co-integration test, and Vector autoregressive model by using monthly data of KSE-100 index and average gold prices October 1993 to May 2014. This study finds that there is no longrun relationship between Karachi Stock Exchange 100 index and gold prices. On the basis of findings, it is concluded investors should not consider KSE 100 index and gold prices as close alternatives rather they should make their decisions on subjective knowledge by aligning them with empirical evidence. While making decisions about gold prices last month's price must be taken into consideration because current gold price is significantly influenced by last month's gold price. Whilst making decision regarding KSE 100 index last two months fluctuations taken into consideration.

\section{References}

[1] Tufail, Saira., and Batool, Sadia. 2013. An Analysis of the Relationship between Inflation and Gold Prices: Evidence from Pakistan. The Lahore Journal of Economics, 18 (2), 1-35.

[2] Nadeem, Warda., Zakaria, Muhammad., and Kayani, F.N. 2014. Impact of Macroeconomic Factors upon Gold Prices in Pakistan. Pakistan Journal of Social Sciences (PJSS), 34 (1), 383-395.

[3] Le, Thai-Ha., and Chang, Youngho. 2011. Dynamic Relationships between the Price of Oil, Gold and Financial Variables In Japan: A Bounds Testing Approach. Available from: http://mpra.ub.unimuenchen.de/33030/.

[4] Bhunia, Amalendu, and Mukhuti, Somnath. 2013. The impact of domestic gold price on stock price indices-An empirical study of Indian stock exchanges. Universal Journal of Marketing and Business Research, 2 (2), 35-43.

[5] Ahmad, Nawaz, Ahmed. R.R., Khoso, Imamuddin.,Palwishah R.I., and Raza, Unaib. 2014. Impact of Exchange Rate on Balance of Payment: An Investigation from Pakistan. Research Journal of Finance and Accounting, 5 (13), 32-42.

[6] Shaheen, Farzan. 2013. Fluctuations in Exchange Rate and its Impact on Macroeconomic Performance of Pakistan. VIII (4), 411 418.

[7] Wogan, Jack. 2010. Is Demand for Gold Seasonal and Does it Follow a Pattern? Available from: http://ezinearticles.com/?IsDemand-For-Gold-Seasonal-and-Does-it-Follow-aPattern?\&id=3796941

[8] Irshad, Hira.,Bhatti,G.A., Qayyum, Abdul.,and Hussain, Haroom. 2012. Long run Relationship among Oil, Gold and Stock Prices in Pakistan.The Journal of Commerce, 6 (4), 06-21.

[9] Sharma, G.D., and Mahendru, Mandeep. 2010. Impact of MacroEconomic Variables on Stock Prices in India. Global Journal of Management and Business Research, 10 (7), 19-26.

[10] Ratanapakorn, O., and Sharma, S.C. 2007, "Dynamic Analysis between the US StockReturns and the Macroeconomic Variables", Applied Financial Economics, $17 \quad$ (4-6), 369-377. http://dx.doi.org/10.1080/09603100600638944.

[11] Moore, G.H. 1990. Gold Prices and a Leading Index of Inflation, $\begin{array}{lllr}\text { Challenge, } & 33 & \text { (4), }\end{array}$ http://dx.doi.org/10.1080/05775132.1990.11471444.

[12] Mahdavi, S., Zhou, S. 1997. Gold and Commodity Prices as Leading Indicators of Inflation:Tests of Long-Run Relationship and Predictive Performance, Journal of Economics and Business, 49, 475489. http://dx.doi.org/10.1016/S0148-6195(97)00034-9.

[13] Soni, N.K., and parashar, Ajay. 2015. Gold Demand increase and its impact on Inflation. Journal of Research in Humanities and Social Science, 3 (2), 10-12.

[14] Büyük $\square$ alvarc1, A. 2010. "The Effects of Macroeconomics Variables on Stock Returns:Evidence from Turkey'.European Journal of Social Sciences, 14 (3), 404-416.

[15] Blose, L.E. and Shieh, J.C.P. 1995. "The Impact of Gold Price on the value of Gold MiningStock", Review of Financial Economics, 4, 125-139. http://dx.doi.org/10.1016/1058-3300(95)90002-0.

[16] Hassan, M. K., 1998. The impact of globalization on the financial market of the developing countries. Journal of economic Cooperation among Islamic Countries, 19, (1-2), 71-135.

[17] Kannan., R. And Dhal Sarat. 2008. India's Demand for Gold: Some Issues for Economic Development and Macroeconomic Policy. Indian Journal of Economics \& Business. 7, (1), 107-128.

[18] United Nation, 2009. The Impact of the Global Financial and Economic Crisis on the Least Developed Countries. Available From: http://unohrlls.org/UserFiles/File/Publications/LDC/UN_Financial_ Crisis 011410 bw.pdf.

[19] Nor, M.I., 2012. The Effect Of Dollarization On Developing Economies: Lessons from Somalia's Informal Market. Academic Research International, 2 (3), 591-597.

[20] Shahzadi, Hina, and Chohan, M., N. 2011. Impact of Gold Prices on Stock Exchange: A Case Study of Pakistan. Available From: http://saicon2011.ciitlahore.edu.pk/economics/1038.pdf.

[21] Jordaan, J., C.2013. Impact of interest rate changes on South African GDP and households: a combined macroeconomic and social accounting matrix modelling approach. Southern African Business Review, 17 (3), 156-186.

[22] Ziaei, S.M., 2012. Effects of Gold Price on Equity, Bond and Domestic Credit: Evidence from ASEAN +3 countries, Procedia- Social and Behavioral Sciences, 40, 341-346. http://dx.doi.org/10.1016/j.sbspro.2012.03.197. 